A VERTICAL EMPIRE 
This page is intentionally left blank 


\section{A VERTICAL EMPIRE}

\section{The History of the UK Rocket and Space Programme, 1950-1971}

\section{N. Hill}

Charterhouse School, UK 


\section{Published by}

Imperial College Pṛess

57 Shelton Street

Covent Garden

London WC2H 9HE

\section{Distributed by}

World Scientific Publishing Co. Pte. Ltd.

P O Box 128, Farrer Road, Singapore 912805

USA office: Suite 1B, 1060 Main Street, River Edge, NJ 07661

UK office: 57 Shelton Street, Covent Garden, London WC2H 9HE

\section{British Library Cataloguing-in-Publication Data}

A catalogue record for this book is available from the British Library.

Front cover photograph: The British Blue Streak rocket being launched at Woomera, Australia. Eleven successful launches of Blue Streak were made between 1964 and 1971. Blue Streak was originally designed as a Medium Range Missile, but later was used as the first stage of the Europa satellite launcher. (C) Crown Copyright. Reproduced with permission.

\section{A VERTICAL EMPIRE}

Copyright $\odot 2001$ by Imperial College Press

All rights reserved. This book, or parts thereof, may not be reproduced in any form or by any means, electronic or mechanical, including photocopying, recording or any information storage and retrieval system now known or to be invented, without written permission from the Publisher.

For photocopying of material in this volume, please pay a copying fee through the Copyright Clearance Center, Inc., 222 Rosewood Drive, Danvers, MA 01923, USA. In this case permission to photocopy is not required from the publisher.

ISBN $\quad 1-86094-267-9$

ISBN $\quad 1-86094-268-7$ (pbk) 


\section{Contents}

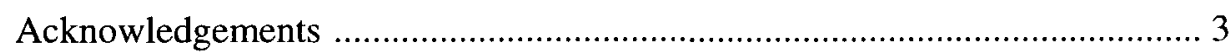

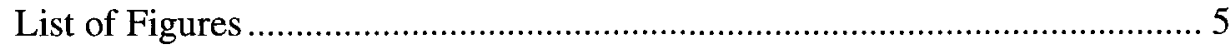

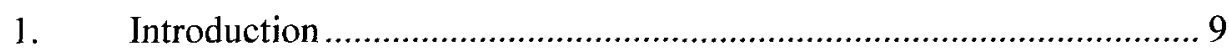

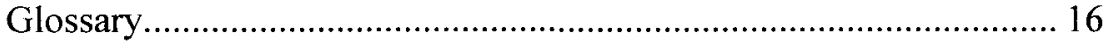

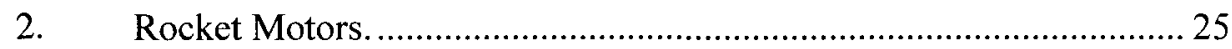

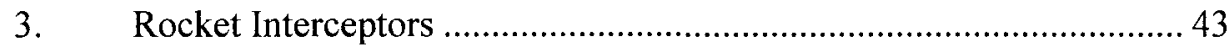

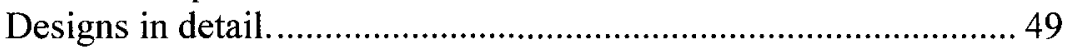

4. The Blue Steel Stand Off Missile........................................................ 59

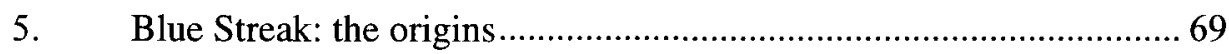

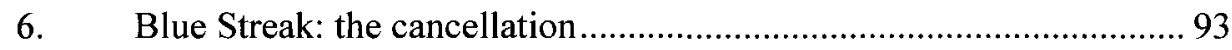

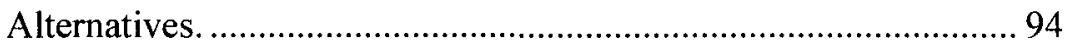

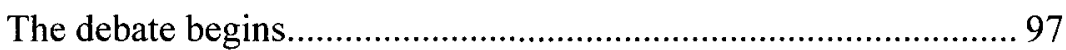

The debate ends....................................................................... 107

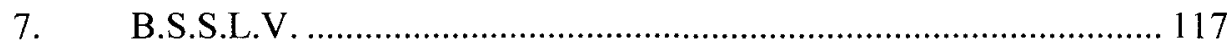

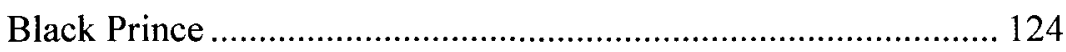

A Liquid Hydrogen stage.......................................................... 128

Combination with Black Arrow................................................... 130

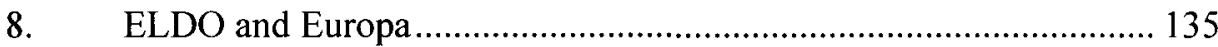

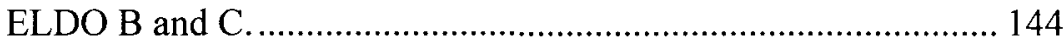

Europa: from success to failure................................................... 147

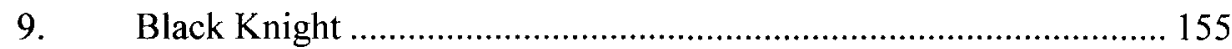

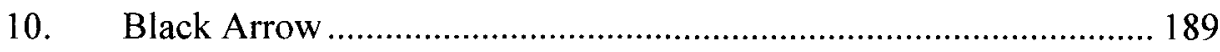

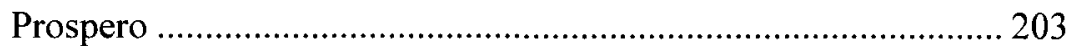

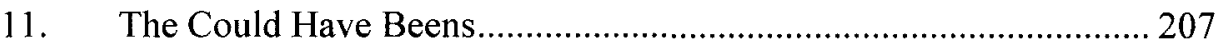


2 A Vertical Empire

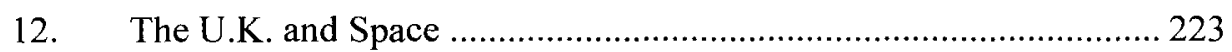

Appendix A-History of the Saunders Roe S.R. 53 and S.R 177................... 239

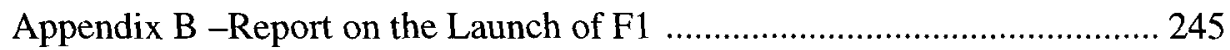

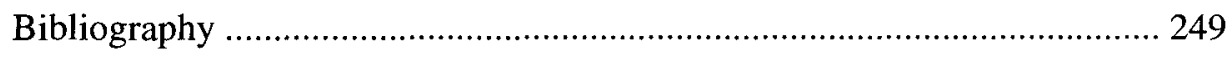

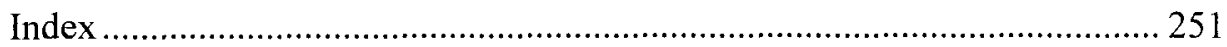




\section{Acknowledgements}

This book would not have been possible without the help given by very many people. Acknowledgments are in alphabetical order.

Roy Dommett C.B.E., of R.A.E. and D.E.R.A., who was involved in much of the work detailed in this book, and whose sharp and percipient comments have thrown light on many of the ideas outlined.

Guy Finch for his encyclopaedic knowledge of aircraft, Blue Streak and the rocket interceptors.

Professor Edward James, who set me on this search following an interview when I applied for his M.A. course in Science Fiction at Reading University, and after reading his book "Science Fiction in the Twentieth Century", where he notes that Dan Dare "gave a whole generation of British boys ... a totally false impression that Britain was going to dominate the space race."

Doug Millard, Space Curator at the Science Museum, who with great kindness started me on my research by allowing me access to his filing cabinet. He also was the first to put the idea in my mind: why do you want to launch satellites anyway?

Kate Pyne, official historian at AWE Aldermaston, for answering blundering questions with tact.

Dave Wright of Manchester University, who has pursued Blue Streak with dogged perseverance, and without those endless telephone conversations this book would not have been possible. Many of the ideas outlined in this book originated from him. Thanks too to his wife Lesley for her patience!

Thanks also to David Cheek of GKN Aerospace, Susan Kinsella, Tom Lukeman, Barrie Ricketson, and the staff of the Public Record Office in Kew for their help and suggestions. Any mistakes are entirely due to me.

Images and copyright:

Thanks to GKN Aerospace for supplying images. Also images from the Defence Evaluation Research Agency: (C) (British) Crown Copyright, 2000 Defence Evaluation and Research Agency, reproduced with the permission of the Controller Her (Britannic) Majesty's Stationery Office. 
This page is intentionally left blank 


\section{List of Figures}

Blue Streak and its Russian and American counterparts. ............................... 12

The SRA/1 ...................................................................................... 23

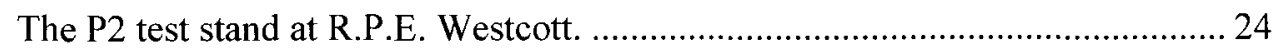

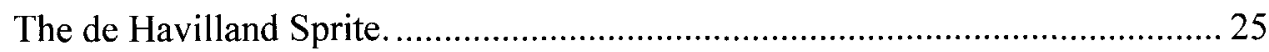

A de Havilland Spectre rocket motor ........................................................... 27

Gamma 301 combustion chamber .......................................................... 29

The large chamber from the Stentor engine............................................. 30

A liquid hydrogen motor being fired at R.P.E. Westcott.............................. 32

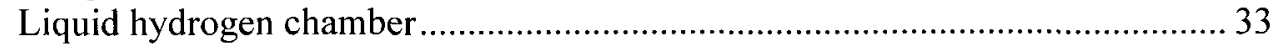

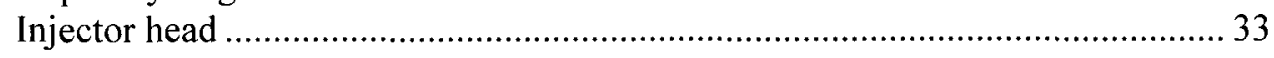

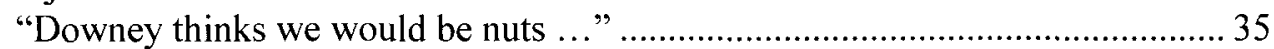

The RZ-20 rocket motor .................................................................... 36

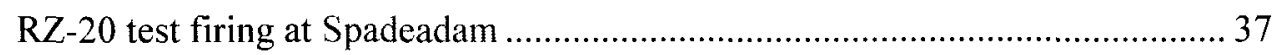

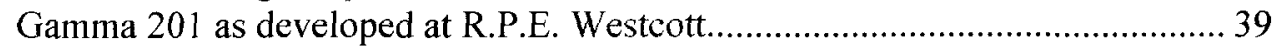

The Gamma 8 engine that powered Black Arrow. ..................................... 41

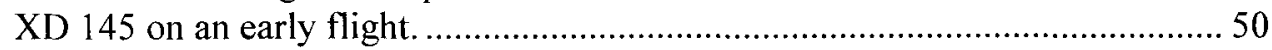

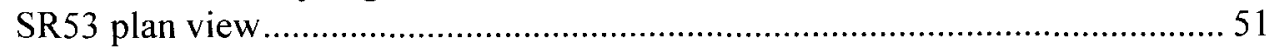

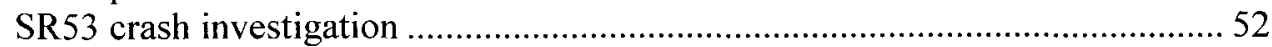

The proposed research programme for the SR53 . ................................... 53

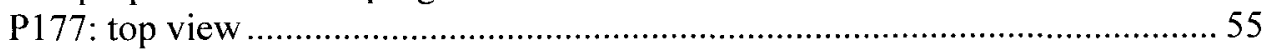

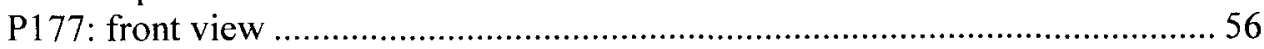

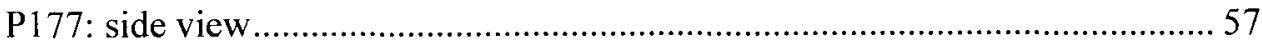

The F177 as it might have appeared in German Air Force colours................... 57

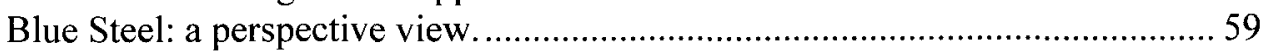

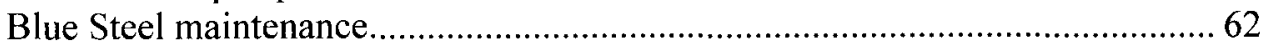

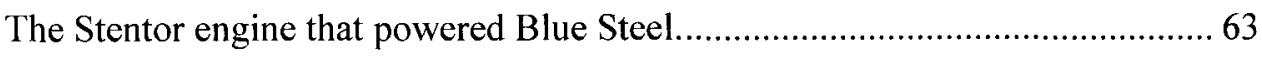

Blue Steel being fitted to a Vulcan bomber................................................ 66

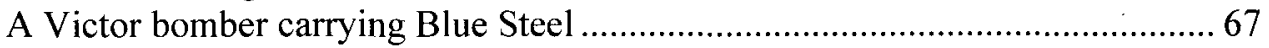

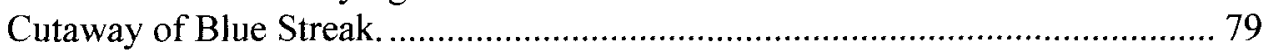

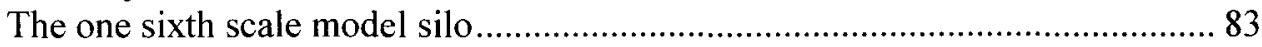

One sixth scale silo. ........................................................................... 84

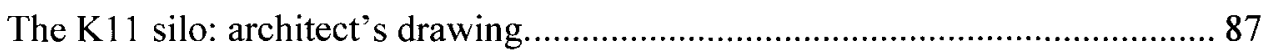

Blue Streak at Hatfield .............................................................................. 91

The air launched ballistic missile Skybolt ................................................... 106

King Hele's proposed Blue Streak/Black Knight launcher ......................... 118

Pardoe's Blue Streak/Black Knight launcher. ........................................... 120

BSSLV: the Ministry of Aviation's view. ................................................. 121 


\section{A Vertical Empire}

Black Prince schematic

Black Prince: from the Saunders Roe brochure............................................ 126

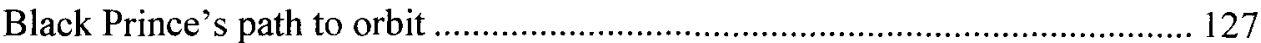

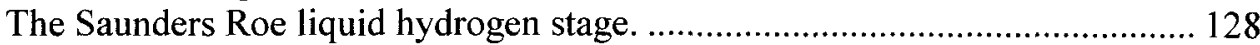

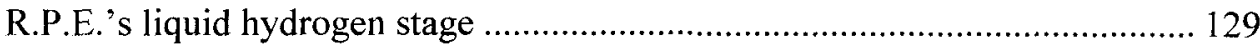

Saunders Roe proposal for Blue Streak/Black Arrow. .................................... 132

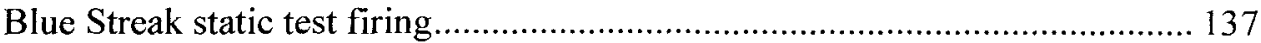

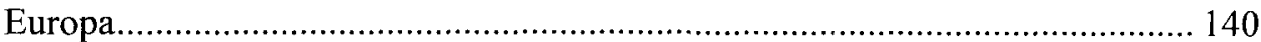

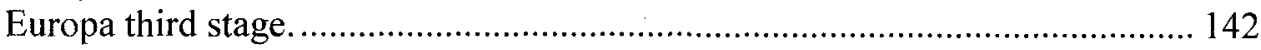

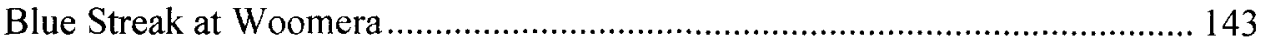

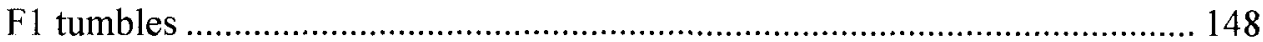

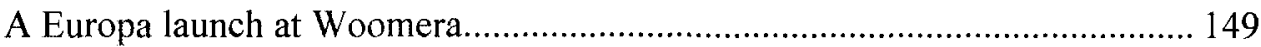

The Blue Streak launch site at Woomera....................................................... 150

A Europa vehicle at Spadeadam ............................................................... 152

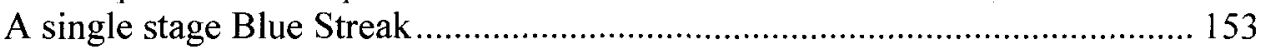

The single stage Black Knight ....................................................................... 157

An early model Black Knight ....................................................................... 158

An aerial view of the High Down site on the Isle of Wight. ............................ 159

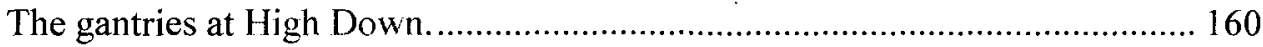

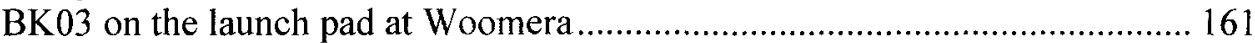

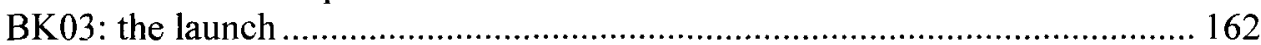

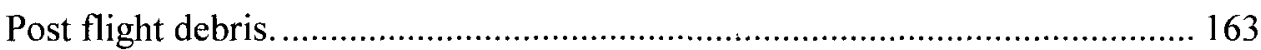

The airflow around a re-entry vehicle at high speed. ....................................... 164

BK04: re-entry head temperatures................................................................ 165

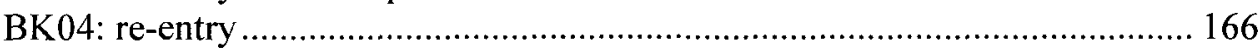

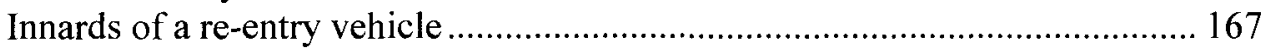

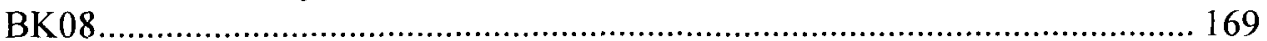

The two stage arrangement ................................................................... 170

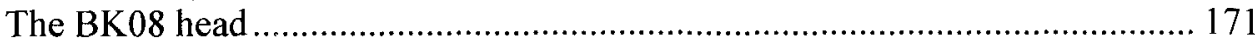

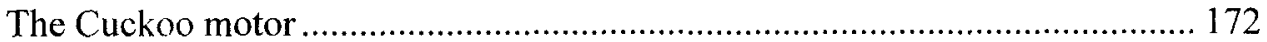

The control centre at Woomera. .................................................................. 174

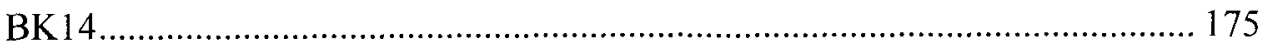

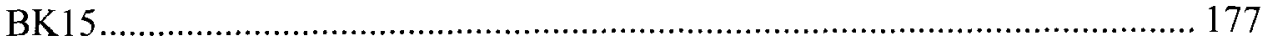

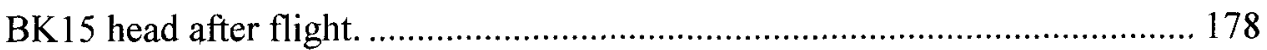

A 86 foot diameter Dazzle radar dish. ........................................................ 179

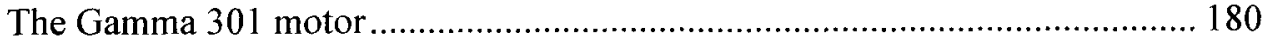

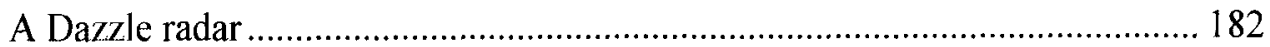

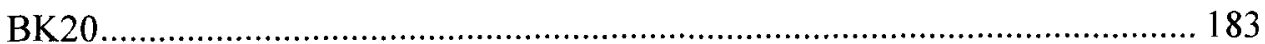

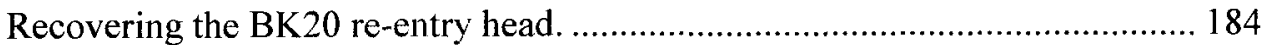

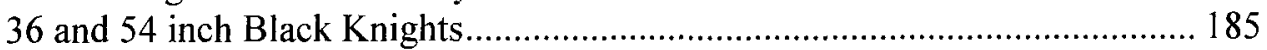

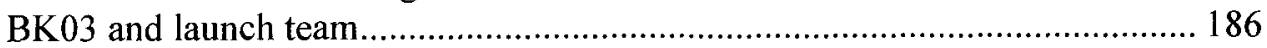

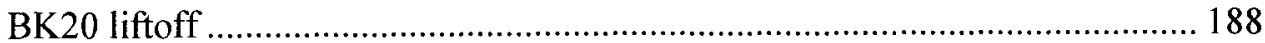

Black Arrow in the static test stand at High Down.......................................... 195

Black Arrow static firing. ............................................................................ 196 
Possible U.K. launch sites for Black Arrow …………..................................... 197

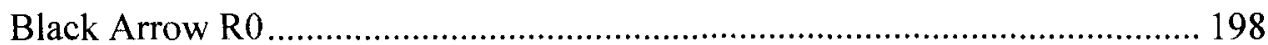

R2 at Woomera

Orba.

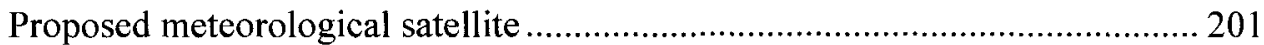

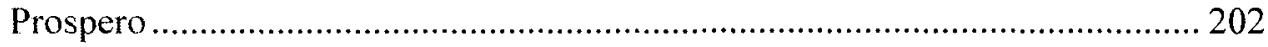

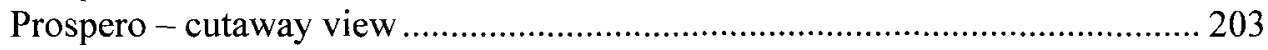

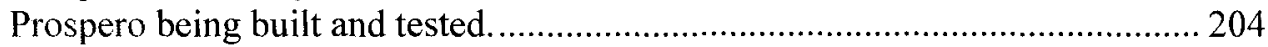

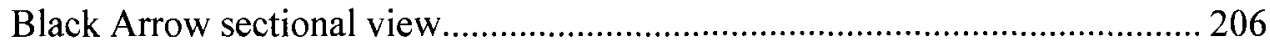

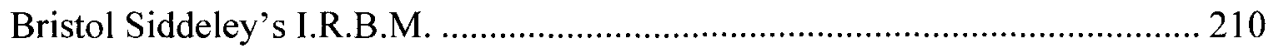

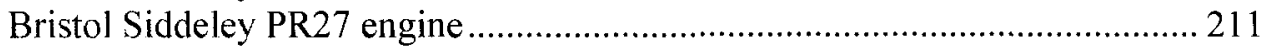

Bristol Siddeley's design for a satellite launcher........................................... 212

Bristol Siddeley's PR38

SLAVE and Black Arrow .......................................................................... 215

Blue Streak with an American Centaur upper stage ....................................... 221

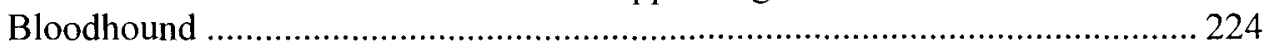

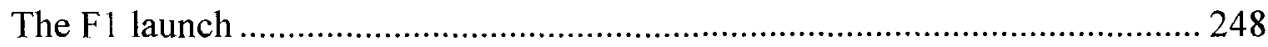

